\title{
Salmonella Serotype Typhi
}

National Cancer Institute

\section{Source}

National Cancer Institute. Salmonella Serotype Typhi. NCI Thesaurus. Code C86926.

Any bacterial organism that can be assigned to the genus Salmonella with serotype

Typhi. 